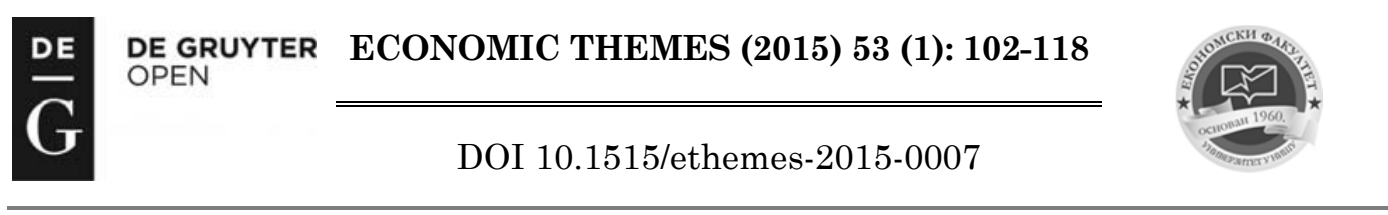

\title{
A STUDY OF THE CONSUMER MOTIVES WHICH INFLUENCE THE PURCHASE OF ORGANIC FOOD IN SERBIA
}

UDC

$336.1(497.11)$

Original

scientific paper

Received:

06.02.2015

Accepted:

03.04 .2015

\author{
Semir Vehapi \\ State university of Novi Pazar, Serbia \\ $\bowtie$ svehapi@np.ac.rs
}

\begin{abstract}
The organic food market in Serbia is in its initial phase of development and can be considered a developing market. A deeper understanding of consumer motivation is possible through an adequate marketing approach which will provide increased organic food purchasing per capita and the quicker development of the national market. This paper presents a selection of the most important findings, which the author obtained from a quantitative study carried out in Serbia. We studied and analyzed the main reasons why people purchase organic food and the obstacles to buying these products, as well as the willingness of consumers to pay a higher price for organic products in comparison to the alternative products obtained from conventional food production systems. The presented results support the theoretical conclusions acquired from numerous previous studies carried out in various countries. Starting from the obtained research results, the conclusion offers a recommendation for the implementation of successful strategies of the marketing mix instruments.
\end{abstract}

Keywords: organic food, motivation, consumers, the market, Serbia

\section{Introduction}

Food consumption is an important and unavoidable part of daily consumption but is also a field which is very important for ecological sustainability. It is estimated that approximately one third of the overall influences of households on the environment are realized through the consumption of food and beverages (Thøgersen, 2010, p. 172). Intensive agriculture of the conventional type pollutes the environment, which leads to the pollution of agricultural and food products. That is why consumers are taking more and more care of their diet, 
health and influence on the environment, and are thus demanding products produced in accordance with their beliefs and lifestyle.

There are several effective means of increasing sustainable food consumption, but the choice of organic food over conventional food is the most important one. "There is no common legal definition of organic food and the term organic refers to as a process claim, not a product claim" (ZakowskaBiemans, 2011, p. 124). Organic food is the result of the application of legally regulated methods of organic production in all the phases of production, which excludes the use of fertilizer, pesticides, growth regulators, additives and genetically modified organisms (GMO).

One of the trends to emerge in the last decade is the increased interest in organic products. The demand for organic food is rapidly increasing, which amounted to the values of the international sale of organic food and drink of approximately 64 billion dollars in 2012. The same year, the per capita consumption of these products was 9,8dollars, with the greatest consumption realized in Switzerland, Denmark, and Luxembourg. Considering that demand is the criterion which drives production, the overall agricultural land meant for organic production reached 37,5 million acres (ha), including land undergoing the process of conversion. If we were to take into consideration the nonagricultural land, which make up more than 31 million ha, in total 69 million ha are thought to be covered by organic soil. There are more than 1,9 million farmers working that land, with most of them working in developed and developing countries (Willer \& Lernoud, 2014).

While the organic food market in Serbia is underdeveloped, the number of organic food producers is rapidly increasing. In 2012 there were 1073 producers working on approximately 6.340 ha of organic agricultural land. The agricultural land meant for organic production makes up $0,1 \%$ of the overall agricultural land in Serbia. This level matches the current level of organic food consumption. The overall turnover in the food sector in Serbia is estimated at 40 million dollars. The average annual expenditures for organic food are 5 dollars per capita, which is a lot less when compared to developed European countries (Willer \& Lernoud, 2014). The main reasons for the still low consumption of organic food in Serbia are the lack of information, the small and uniform offer of organic food products, underdeveloped channels of distribution, as well as the low income of the population.

Understanding the motivation of consumers when purchasing organic food is of vital importance for the implementation of successful marketing strategies, primarily communication strategies, and consequently for the much quicker development of the organic food market. The reasons why consumers purchase organic products and the obstacles to their consumption of a certain product provides a basis for a deeper analysis of the needs and motives of the 
consumers. As a result, the focus of this paper will be the determination of the motives why consumers purchase organic food and the obstacles they perceive to buying it. Even though a large number of foreign authors have studied the motivation factors which condition or hinder the purchase of organic food, such studies are infrequent in Serbia. Accordingly, the aim of the author is to analyze and present the main reasons why consumers purchase organic food and the obstacles to the consumption of organic food in Serbia. The paper offers an overview of the existing literature, which outlines the most important results obtained both locally and abroad, pertaining to the motivation of consumers on the organic food market. In the third section of the paper, we present the basic aims and hypotheses of the research, as well as the research techniques. The following segment represents the research results which refer to consumer motives and their willingness to pay premium price for organic food on the Serbian market. In the end, we offer some concluding remarks and give recommendations for the development of successful strategies of the marketing mix instruments.

\section{Literature Overview}

The research into the motives of human behavior, especially unconscious and hidden motives, has a special place in the theory of consumer behavior (Maričić, 2011, p. 437). Numerous researchers have carried out motivational studies on the organic food market, especially in countries in which this market is developed. The motivation for purchasing organic food is mostly motivated by the desire to preserve one's health, by care for the environment, by the consumer's sensory features, general food safety and by various ethical reasons. Organic products are perceived as products which have an advantage in terms of the positive influence on the health of individuals, especially in comparison to their inorganic alternatives (Torjusen et al., 1999; Magnuson et al., 2001; Lea \& Worshey, 2005; Radman, 2005; Renko \& Bošnjak, 2009; Zakowska-Biemans, 2011; Truong et al., 2012). The perception of organic food as having more health benefits in comparison to conventionally grown food is a predictor of more frequent purchasing (Brčić-Stipčević \& Petljak, 2011). Many studies identify health as the main motive for purchasing organic products, indicating that most consumers buy these products for health reasons (Tregear et al., 1994; Hutchins \& Greenhalgh, 1997; Schifferstein \& Oude Ophuis, 1998; Squires et al., 2001; Chinnici et al., 2002; Makatouni, 2002; Padel \& Foster, 2005; Magistris \& Gracia 2008; Marques Vieira et al., 2013). Health includes both personal and family health, where Padel \& Foster (2005) indicate that individual health is a stronger motivator for purchasing products than family health. However, organic products do not only preserve the health of the consumers, but also protect the health of the producers (Miller \& Spoolman, 2008). Another motive which is closely related to health and which could lead to the purchase 
of organic food is the absence of pollutants and chemicals (Ekelund, 1990; Aertsens et al., 2011; Soil Association 2012). In addition to health, contribution to the preservation of the environment is often a highly ranked motive for the purchase of organic food (Davies, et al., 1995; Torjusen et al., 1999; Von Alvensleben, 1998; Aguirre, 2001; Aertsens et al., 2011; Marques Vieira et al., 2013; Pearson et al., 2013). Considering that organic production excludes the use of chemicals and pesticides, the consumers perceive organic food as ecologically "friendly" (Wilkins \& Hillers, 1994).

Three important factors which could also influence the decision to buy organic food are safety, quality and flavor (Truong et al., 2012). The onset of various illnesses such as BSE (Mad Cow disease) and Salmonella poisoning have led to increased worry on the part of consumers over food produced by means of conventional methods. Numerous consumers believe that organic food is safer than the conventionally produced alternatives (Wang et al., 1997; Zakowska-Biemans, 2011). Thus, safety can be a primary motive for the purchase of this type of food (Soler et al., 2002; Zakowska-Biemans, 2009; Vlahović et al., 2011). Safety is especially important for meat consumption (O'Donovan \& McCarty, 2002). Quality and taste can represent significant motives for the consumption of organic products (Schifferstein \& Oude Ophuis, 1998; Magnuson et al., 2001; Driouech et al., 2013; Vlahović et al., 2011). Production-based quality is often described as the higher content of vitamins and nutrients in organic food (Zagata, 2012), but also as the appearance of the product (Thompson \& Kidwel, 1998). Organic food has a greater nutritive value when compared to conventional food (Del Amor, 2007; Amodio et al., 2007). Even though consumers consider organic products to be of good quality and taste, they are often dissatisfied with the appearance of the products (Radman, 2005). This means that appearance can have a significant effect on the purchase of these products (Kuhar \& Juvančič, 2010). When speaking of taste, Znaor (1996, p. 387) points out that organic products offer far superior results to conventionally grown products, and thus are the only appropriate ones for the preparation of specialty dishes. Kihilberg \& Risvik (2007) discovered in their study that most consumers consider processed organic food (bread) to be tastier than the alternative products from conventional production and processing systems.

Among the ethical motives which are related to the purchase of organic food, the welfare of animals, as well as support that is offered to the local farmers and the local community are all singled out for their importance. (Fotopoulos and Krystallis, 2002; Aarset et al, 2004; Sangkumchaliang et al, 2012).Organic agriculture creates the conditions to sustain the natural life cycle of animals, which includes the ability to manifest their natural behavior, food which is better suited to animal psychology and environments which are similar to the natural animal biotope. Organic production based on knowledge and the 
use of local resources enables small farmers to take part in this type of production. This influences the increase in the number of employees and stimulates producers to stay in the field of agricultural production and to invest in rural areas.

In explaining the motives for the consumption of organic food, it is necessary to emphasize the presence of regional differences which are reflected in the following (Bonny, 2006, p. 11):

- Care for one's own health is the primary motive with $51 \%$ of the overall motivation on the global level, and is the most frequently cited argument among the inhabitants of Asia, North America and Latin America;

- Care for the health of children makes up $17 \%$ of the overall motivation, but has the highest frequency in Indonesia, Mexico, Brazil and Turkey;

- Ecological motivation (on average $15 \%$ of the overall motivation) is the most important in the Philippines, in Sweden, Hong Kong, Norway, South Africa, Thailand, France and other European countries;

- The welfare of animals makes up 7\% of the reasons on the global scale and is most highly ranked in Austria, Germany and Switzerland.

The main obstacles to the purchase of organic food are its high price, limited availability, satisfaction with conventionally produced food and the lack of trust in organic products. Numerous studies have indicated that the price is the main obstacle to the increased production of organic food (Tregear et al, 1994; Zanoli and Naspeti, 2002; Leifert and Bourlakis, 2004; Padel and Foster, 2005; Brčić-Stipčević and Petljak, 2011; O'Doherty Jensen et al. 2011; Soil Association, 2012). An analysis of the motives why consumers do not purchase organic products confirms that the price is the primary motive in many countries (Table 1). However, studies in different parts of the world reveal that certain groups are willing to pay premium price for organic products (Ekelund, 1990; Goldman and Clancy, 1991; Aguirre, 2011; Wolf, 2002, O'Donovan and McCarty, 2002; Aryal et al, 2009; Vlahović et al; 2011). The willingness to pay a higher price for organic food depends on the type of product, frequency of purchase as well as the socio-demographic characteristics of the consumers. Urena et al. (2008) emphasize that regular consumers and males are willing to pay a higher price for these products. Hutchinson \& Greenhalgh (1997) discovered that consumers were willing to pay as much as $20-30 \%$ more for organic meat in comparison to other categories of organic food. By analyzing other studies, Wier \& Carlverley (2002) proved that only 5-20\% of consumers will buy organic food when premium prices are greater than $30 \%$, while premium prices between $10-30 \%$ attract $10-50 \%$ of the consumers. This means that the demand for organic food has price elasticity (Gavruchenko et al, 2003), and that a greater drop in the price would contribute to the significant increase in the demand for organic products. 
Table1The Main Obstacles to Buying Organic Food in a Number of Selected Countries

\begin{tabular}{|l|l|}
\hline Country & Main obstacles to buying organic food \\
\hline Austria & $\begin{array}{l}\text { The price, habit, lack of trust and lack of motivation, poor product } \\
\text { availability, unsatisfactory assortment of products }\end{array}$ \\
\hline Switzerland & $\begin{array}{l}\text { The price, the low level of perception of the differences between } \\
\text { organically and conventionally grown food, a lack of trust in the } \\
\text { organic standards }\end{array}$ \\
\hline Germany & $\begin{array}{l}\text { The price, lack of product availability, habit, doubts as to the } \\
\text { quality of the organic products, a lack of interest, taste }\end{array}$ \\
\hline Finland & $\begin{array}{l}\text { Consumers sensitive to prices under the influence of doubtful } \\
\text { quality }\end{array}$ \\
\hline Italy & $\begin{array}{l}\text { availability, lack of confidence in the standard, the quality of the } \\
\text { organic products, the price (regular consumers) }\end{array}$ \\
\hline Great Britain & $\begin{array}{l}\text { Connection with the product (the price, appearance, availability of } \\
\text { the quality, diversity, taste), information on the product (lack of } \\
\text { transparency, trust, other information) }\end{array}$ \\
\hline Croatia & The price and insufficient information regarding the product \\
\hline Serbia & The price and lack of trust in the producers \\
\hline SAD & The price and the availability of the organic products \\
\hline \multicolumn{1}{|c|}{ Source: Brčić-Stipčević, et. al., (2010); Vlahović et al., (2011); and Dimitri and } \\
&
\end{tabular}

The lack of availability is often cited as the main obstacle to purchasing organic food (Davies et al, 1995; Soler et al, 2002; Lea and Worshey, 2005; Zakowska-Biemans, 2007; Renko and Bošnjak, 2009). Organic food is still present only in limited amounts and is not easily available to consumers (Zanoli and Jukić, 2005). This means that availability is significantly related to the intent to purchase these products (Kuhar and Juvačić, 2006; Marques Vieira et al, 2013). There are consumers who do not purchase organic food since they are satisfied with the conventionally grown kind (Roddy et al, 1994; Magnusson et al, 2001). Jolly et al. (1989) suggest that the main reason why some consumers do not buy organic food is related to their perception that it is not better than the conventional alternatives. The mistrust of some consumers toward organic products is linked to their skepticism about certification bodies and organic labels. Namely, many consumers still have problems recognizing organic products, but do not believe that the product was manufactured by organic means, citing that these are the main barriers which deter them from purchasing organic food (ZakowskaBiemans, 2011; Vlahović et al, 2011; O'Doherty Jensen et al. 2011). The standardization of the regulations for organic production and the introduction of a unique system of marking for organic production within the European Union (EU) have made a significant contribution to overcoming the problem in terms of the lack of trust in these products. 


\section{The Research Methodology and Research Questions}

Bearing in mind all the aforementioned, as well as the fact that per capita consumption of organic food in Serbia is significantly lagging behind the average per capita consumption in Europe, the set aim in the research carried out in Serbia was to discover the influence of most important reasons why people purchase organic food and the obstacles which prevent them from buying organic food. In the realization of the set goal, we started from the following groups of research questions:

1) What are the motives for purchasing organic food in Serbia? Can health be considered the primary motive for the purchase of organic food? What are the other important motives?

2) What are the main reasons for not purchasing or purchase limited amounts of organic food in Serbia? Can the price be considered a barrier which repels the consumers from purchasing or prevents the purchase of any greater amounts of organic food? What are the other important obstacles?

3) Are consumers in Serbia willing to pay for the organic food products, and to which extent? Can the demand for organic food in Serbia be considered as price elastic?

The answers to the aforementioned questions can be used to create successful mix marketing instrument strategies, primarily promotion and pricing strategies. In the final outcome, that should have a doubly positive effect: (1) finding the most effective means of communication with the consumers should contribute to the education of consumers and the promotion of the greater consumption of organic food in Serbia; and (2) adapting the marketing mix instruments to the current demand in order to create greater competitiveness and better positioning of the producers of organic food.

In the study of consumer motives we can use both quantitative and qualitative research methods (Ognjanov et al, 2010). The study presented in this paper is based on the findings obtained in a quantitative study carried out by means of the survey technique. The instrument used was a structured questionnaire which included a list of questions, mostly of the closed type. In addition, the scale technique was also used. In order to determine the reasons why people purchase organic food and the obstacles to purchasing it, we used a ranking scale, while the willingness to pay for organic food was determined using the multiple choice question type.

The research was carried out on an appropriate sample which included 212 participants from the biggest cities in Serbia: Belgrade, Novi Sad, Niš, Kragujevac and Novi Pazar. When determining the sample, we made sure that the units selected from each city were proportionally similar to the number of

\footnotetext{
${ }^{1}$ This research is a part of a wider study on the attitudes of consumers related to organic food in Serbia.
} 
citizens. Despite the fact that it is a relatively small representative sample, we can consider that the obtained answers are sufficiently indicative of the important factors of organic food demand. In order to realize the aim of the study, we relied on a combination of an e-mail survey and individual interviews, where the participants were questioned in person on various locations, including high schools, faculties and even stores. Approximately three weeks were set aside for the survey, from May 8 to June 3, 2014 when the survey was completed. The data analysis was carried out using the SPSS statistical package for social sciences, while the results presented in this paper were obtained by means of descriptive statistics. In the remainder of this paper, we discuss the hierarchy of the motives for buying and not buying/buying limited amounts of organic food, as well as the willingness of the consumers to pay for this product category. In addition, the obtained results were analyzed and compared to those of previous studies focusing on the consumption of organic food on the Serbian market in order to indicate the possibility of a change in consumer behavior.

\section{The Results and Discussion}

\subsection{The Motives for Purchase of Organic Food in Serbia}

In order to identify the most important motives for purchasing organic food, the respondents were asked to rank the following ten motives based on their importance: health, environmental protection, safety, quality, taste, freshness, the lack of pesticides and GMO, the welfare of animals, resource protection for further generations and support for the local/small agricultural producers. The question was addressed to the consumers who had stated that they were familiar with the term "organic food" and who purchase these products $(n=174)$.

The research results indicate that health is the most important motive for purchasing organic food in Serbia. As much as $81,6 \%$ of consumers ranked health as their leading motive. The other most frequently cited motives, ranked second and third, are quality $(25,9 \%)$ and safety $(23 \%)$. According to the classification of the production attributes offered by Grunert et al. (2000), health and safety belong to the attributes which were awarded credence, while certain quality dimensions (such as taste) are marked by experiential attributes. This means that credence and experiential attributes have the greatest influence on the intent to purchase organic food among consumers in Serbia. On the other hand, the least important motives classified by most of the consumers include the welfare of animals $(26,4 \%)$, preserving resources for future generations $(38,5 \%)$ and support for the local/small producers $(43,1 \%)$. What is interesting, and which does not match the results obtained in most European countries, is the finding that the protection of the environment was ranked very low (7th place) on the ladder of hierarchical motives (Table 2). This can only be the 
consequence of an insufficiently developed ecological awareness of the consumers in this market. However, these results match the results obtained in previous studies carried out on the Serbian market. Vlahović et al. $(2010,2011)$ found that health benefits and quality are the basic motives for purchasing organic agricultural and food products. Ognjanov et al. (2010) in their study also prove that health and taste are the most important motives for the consumption of fruit in Serbia. ${ }^{2}$

Table 2 The Descriptive Indicators of the Ranking of Motives for the Purchase of Organic Food

\begin{tabular}{|c|c|c|c||}
\hline Rank & $\mathbf{N}$ & Modus & $\mathbf{\%}$ \\
\hline 1. & 174 & Health & 81,6 \\
\hline 2. & 174 & Quality & 25,9 \\
\hline 3. & 174 & Safety & 23,0 \\
\hline 4. & 174 & Quality & 24,7 \\
\hline 5. & 174 & Taste & 22,4 \\
\hline 6. & 174 & Freshness & 18,4 \\
\hline 7. & 174 & Environmental protection & 24,1 \\
\hline 8 & 174 & Animal welfare & 26,4 \\
\hline 9. & 174 & $\begin{array}{c}\text { Preserving resources for future } \\
\text { generations }\end{array}$ \\
\hline 10. & 174 & $\begin{array}{c}\text { Support for the } \\
\text { local/smallfarmers }\end{array}$ \\
\hline
\end{tabular}

Source: The data which the author obtained in his own fieldwork

\subsection{The Reasons for Deciding Against Purchasing or Limiting the Purchase of Organic Food in Serbia}

In order to discover the most important obstacles to purchasing organic food, the respondents had the task of ranking the following seven barriers based on level of importance: price, availability, a less appealing appearance, mistrust of organic labels, limited offer, the lack of available information and promotion, as well as disinterest. This question was addressed to all the respondents familiar with organic products, both buyers as well as participants who did not purchase organic food $(\mathrm{n}=203)$.

\footnotetext{
${ }^{2}$ This study covered the various categories of fruit, that is, food, both conventional, traditional and organic.
} 
The research results shown in Table 3 reveal that the price is the basic obstacle to purchasing organic food. Almost one third of the consumers $(30 \%)$ provided a hierarchy of barriers in their responses at whose top they placed the price of the products. The price of organic food of most Serbian producers is on average up to $30 \%$ higher in relation to the alternative products obtained from conventional production practices, but is clearly still too high for many consumers from the Serbian national market. The other barriers ranked high in the hierarchy include the lack of availability and the limited offer of organic food. Namely, 23,2\% consumers rank lack of availability as the secondary motive, with $21,2 \%$ consumers ranking the poor range of products as the tertiary motive for not purchasing or the limited purchase of organic food. This only confirms the fact that in Serbia the channels of distribution are insufficiently developed and that there is no adequate wide assortment of products, sufficient amount of products and consistent offer. Wholesale, supermarkets and hypermarkets have the greatest share in the structure of the overall channels of distribution, with a significantly smaller involvement of the other channels. The most frequent categories of organic food in the product assortment of producers from Serbia are grains, fresh vegetables, fresh fruit and dry fruit, with a very small presence of processed organic food. Unlike the main obstacles, the less appealing appearance of organic food (26\%) and consumer disinterest $(49,3 \%)$ are usually cited as the least important reasons for limiting or preventing the purchase of these products. Another important finding is the fact that consumers in Serbia do not ascribe great importance to the appearance of the products as a criterion of determining whether to purchase some types of food or not. The obtained results partially match the results of previous studies on the Serbian national market. Vlahović et al. $(2010,2011)$ suggest that the distrust of organic products is the primary motive, while price is the secondary motive for not purchasing these products. Ognjanov et al. (2010) concluded that the limitations of time and price are the deciding factors for the greater consumption of fruit.

Table 3 The Descriptive Indicators of the Obstacles to Purchasing Organic Food

\begin{tabular}{||c|c|c|c||}
\hline Ranking & $\mathbf{N}$ & Modus & $\mathbf{\%}$ \\
\hline 1. & 203 & The price & 30,0 \\
\hline 2. & 203 & Lack of availability & 23,2 \\
\hline 3. & 203 & Limited offer & 21,2 \\
\hline 4. & 203 & Limited offer & 20,7 \\
\hline 5. & 203 & Lack of trust in organic labels & 22,2 \\
\hline 6. & 203 & Less appealing appearance & 26,6 \\
\hline 7. & 203 & Lack of interest & 49,3 \\
\hline
\end{tabular}

Source: The data which the author obtained himself in his field work 


\subsection{The Willingness of Consumers to Pay for Organic Food in Serbia}

Within these research questions, the respondents were offered more price options for organic food, which were gradually ranked according to the amount, from the current price, to prices twice as great in comparison to conventionally produced food. The respondents were then asked to select the maximum price which they were willing to pay in order to determine whether the demand decreases with an increase in price. The condition for answering this question was whether the respondents were familiar with the prices and purchased organic products $(\mathrm{n}=174)$.

Figure 1 A Simulation of Price Elasticity of Demand for Organic Food in Serbia

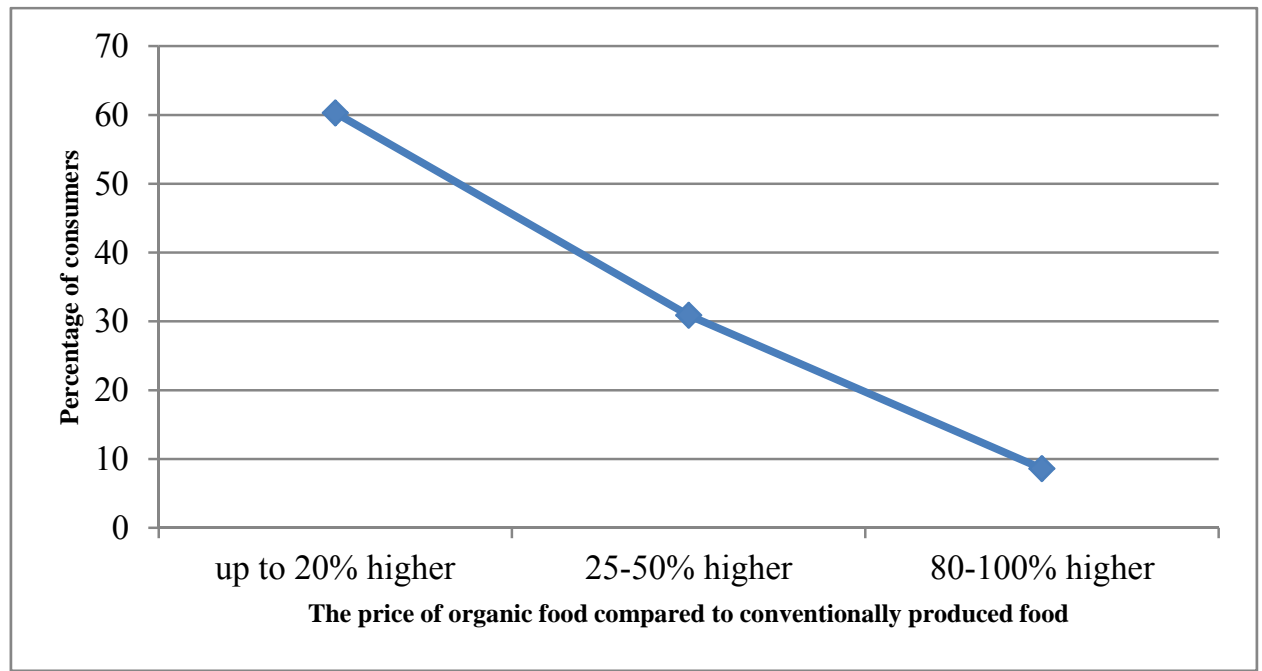

Source: Data the author himself obtained in his fieldwork

Despite the fact that the average salary in Serbia is far below the average salary in the EU, a high percentage of consumers $(89,1 \%)$ are willing to pay a higher price for organic food in comparison to the same types of conventionally produced items. However, the percentage of consumers decreases with the increase in the price of organic food. According to the research results, $63 \%$ of the buyers are willing to pay up to $20 \%$ higher price, and $30,9 \%$ of the buyers would pay $25-50 \%$ higher price, while only $3,6 \%$ would pay $80-100 \%$ higher price for organic food products in comparison to the conventionally produced alternatives (figure1). This means that the demand for organic food in Serbia is price elastic. The results of previous studies carried out in Serbia are in agreement with the findings in this study. Namely, according to the previous results, the greatest percentage of consumers $(36 \%)$ are willing to pay a price which is $20 \%$ higher, while a negligibly smaller number of consumers $(2 \%)$ are 
willing to pay $50 \%$ more for organically produced agricultural products (Vlahović et al, 2010). The key reason for such a high sensitivity of consumers to the price of organic products is their low life standard, but also the insufficient level of information on the actual importance of products obtained using organic methods of production.

\section{Conclusion and Recommendations}

Based on the results of this quantitative study carried out in Serbia, it can be concluded that health is the most important motive for the purchase of organic food. Such a result matches the findings of numerous studies previously carried out in various countries, including Serbia, which speaks in favor of the overall theoretical knowledge that health is an important motivation factor in organic food consumption. Along with health, quality and safety also emerge as important motives for the purchase of organic products. Considering that the consumers in Serbia are mostly motivated by health and hedonic motivation, this research discovered that a high level of safety and hedonism are important characteristics of these consumers. What also motivates the consumers of this market is the insufficient presence of ethical and ecological motives for purchasing organic food, which makes them stand apart from consumers in developed countries.

Consumers who do not purchase organic food or do so rarely and in limited amounts, only do so as a result of the higher price of these types of products in comparison to the same type of products produced using conventional food production systems. The recognition of the price as the main obstacle to purchasing these goods is in accordance with the findings presented in the theoretical part of the study. In Serbia, organic food products are cheaper than those found on the markets of more developed countries, but at the same time still too expensive for the consumers on the local market, considering their weak purchasing power. The willingness of consumers to pay for organic food decreases with the increase in its price. This means that the basic characteristic of the organic food market in Serbia is the high price elasticity of demand. In addition to price, the lack of availability and the limited offer are also significant obstacles to purchasing this type of food. The limited availability and offer are the result of the immature nature of the market in Serbia. The national market of organic food is in its initial phase of development and can be considered a developing market. On such a market, the behavior of consumers in relation to motivation has not changed over the last few years, which indicates the agreement of the results obtained in this research and those of previous studies carried out in Serbia.

Understanding the motives of consumers regarding their choice of food is essential for the creation of successful marketing strategies. The aforementioned 
results can be used with the aim of developing effective strategies of the marketing mix instruments and the consequent increased development of the national organic food market. First and foremost, the individuals who make these decisions in the public sector should be interested in initiating educational campaigns which they would use to inform the population of the means of obtaining and labeling organic food, and the actual importance of these products for sustainable development. This is the only way for the population to be able to note the actual difference between organic food and the remaining food categories, primarily health food, and a way of offering an accurate image of the obtained values which require a higher price. On the other hand, the profit sector can also help by initiating extensive advertising campaigns which would be used to promote the consumption of organic food. Considering the significant presence of safety and hedonistic motives, these campaigns should promote the health benefits, nutritive values and appealing taste of organic food. However, the consumption of these products can be promoted through the use of ethical and ecological appeals, by emphasizing responsibility for the welfare of animals, people and the environment. This would contribute to consumers of organic food feeling like responsible citizens and good neighbors.

Since the price is the most important obstacle to purchasing organic food, the pricing strategy should focus on the decrease in the price of these products. This certainly requires a better organization of the supply chain from the producer to the consumer. In order for the production strategy to enable the realization of the low-pricing strategy, the profit sector is expected to increase the extent and assortment of organic food, primarily through the introduction of processed and traditional products. A wider assortment of products, based on the effects of the economy of scale, would decrease the expenses involved in the production of organic food, while a wider range of products would solve the problem of the limited assortment of products offered on the national market. The distribution strategy should be created in such a way so that the organic food would become available in various locations. Solutions offered within this strategy should be sought in the development of the HORECA channel, which includes providing products for hotels, restaurants and cafes. Thus, organic food would become more available to potential consumers even when they are not in their homes.

\section{References}

Aarset, B., Beckman, S., Bigne, E., Beveridge, M., Bjorndal, T., Bunting, J., McDonagh, P., Mariojouls, C., Muir, J., Prothero, A., Reisch, L., Smith, A., Tveteras, R. and Young, J. (2004) "The European consumers' understanding and perceptions of the "organic" food regime: the case of aquaculture", British Food Journal, 106 (2): 93-105.

Aertsens, J., Mondelaers, K., Verbeke, W., Buysse, J. and Huylenbroeck, G.V. (2011) "The influence of subjective and objective knowledge on attitude, motivations and consumption of organic food“", British Food Journal, 113(11): 1353-1378. 
Aguirre, G.J.A. (2001) "Marketing and consumption of organic products in Costa Rica", Working Paper, No. 5, The School for Field Studies, Centre for Sustainable Development, Atenas, Costa Rica.

Amodio, M.L., Colleli, G., Hosey, J.K. and Kader, A.A. (2007) "A comparative study of composition and postharvest performance of organically and conventionally grown kiwifruit", Journal of Science of Food and Agricultural, 87(7): 1228-1236.

Aryal, K.P., Chaundhary, P., Pandit, S. and Sharm, G. (2009) “Consumers' Willingness to Pay for Organic Products: A case from Kathmandu Valley", Journal of Agriculture and Environment, June 10: 15-26.

Bonny, S. (2006) “Organic Farming in Europe: Situation and Prospects”, Notre Europe, Paris, France, November,http://www.notre-europe.eu/media/bonny_agribio-en.pdf?pdf=ok [Accessed January 14, 2014]

Brčić-Stipčević, V., Petljak, K. and Guszak, I (2010) "Što utiče na kupnju ekoloških prehrambenih proizvoda?", in: Katalinić, B. (ed.), Vallis Aurea - focus on Regional Development, Požega (Croatia): Polytechnic of Požega, Croatia \& DAAM International Vienna, Austria, pp. 149-155.

Brčić-Stipčević, V. and Petljak, K. (2011) "Research on organic food purchase in Croatia", Tržište, 23(2): 189-207.

Chinnici, G., D'Amico, M. and Pecorino, B. (2002)“ A multivariate statistical analysis on the consumers of organic products", British Food Journal, 104 (3/4/5): 187-199.

Davies, A., Titterington, A. and Cochrane, C. (1995) "Who buys organic food? A profile of the purchase of organic food in Northern Ireland“, British Food Journal, 97 (10): 17-23.

Del Amor, F.M. (2007) "Yield and fruit quality response of sweet pepper to organic and mineral fertilization", Renewable Agriculture and Food Systems, 22 (3): 233-238.

Dimitri, C. and Oberholtzer, L. (2005) "Market-led Versus Government-Facilitated Growth: Development of the U.S. and EU Organic Agricultural Sectors, Electronic Outlook Report, WRS-05-05, Economic Research Service, USDA, August.

Driouech, N., Capone, R., Dernini S.., Berjan, S., El Bilali, H., Radović, M., Despotović, A., Panin, B. (2013) "Consumer perceptions of agro-food products with ethical values in Serbia: an exploratory study”, International Journal of Nutrition and Food Sciences, 2 (3): 153-159.

Ekelund, L. (1990) "Vegetable consumption and consumer attitudes towards organically grown vegetables - the case of Sweden", Acta Horticulturae, 259: 163-172.

Fotopoulos, C. and Krystallis, A. (2002) "Organic product avoidance: reason for rejaction and potential buyers' identification in a countrywide survey", British Food Journal, 104 (3/4/5): 233-260.

Gavruchenko, T., Baltas, G., Chatzitheodoridis, F. and Hadjidakis, S. (2003) "Comparative marketing strategies for organic olive oil: the case of Greece and Holland", In : Nikolaidis A., Baourakis G., Isikli E., Yercan M., (eds.), The market for organic products in the Mediterranean region, Chania: CIHEAM, pp. 247-255.

Goldman, B.J. and Clancy, K.L. (1991) "A survey of organic produce purchases and related attitudes of food cooperative shoppers", American Journal of Alternative Agriculture, 6 (2): 89-96.

Grankvist, G. and Biel, A. (2001) "The importance of beliefs and purchase criteria in the choice of eco-labelled food products", Journal of Environmental Psychology, 21 (4): 405-410. 
Grunert, K.G., Bech-Larsen, T. and Bredahl, L. (2000) "Three issues in consumer quality perception and acceptance of dairy products", International Dairy Journal, 10 (8): 575584.

Hutchins, R.K. and Greenhalgh, L.A. (1997) "Organic confusion: sustaining competitive advantage", British Food Journal, 99 (9): 336-338.

Jolly, D.A., Schutz, G.H., Diaz-Knauf, K.V. and Johal, J. (1989) "Organic foods: Consumer attitudes and use", Food Technology, 43 (11): 60-65.

Kihilberg, I. and Risvik, E. (2007) "Consumers of organic foods - value segments and liking of bread", Food Quality and Preference, 18 (3): 471-481.

Kuhar, A. and Juvančič, L. (2006) "What determines integrated and organic fruit and vegetable consumption in Slovenia?", Jahrbuch der Osterreichischen Gesellschaft fur Agrarokonomie, 15 (1): 23-33.

Kuhar, A. and Juvačič, L. (2010) "What determines purchasing behavior for organic and integrated fruits and vegetables?", Bulgarian Journal of Agricultural Science, 16 (2): 111-122.

Lea, E. and Worsley, T. (2005) “Austrlians' organic food beliefs, demographics and values“, British Food Journal, 107 (11): 855-869.

Leifert, C., Bourlakis, M., (2004) "Recent Developments in the EU Organic Food Market", Acorn Conference, 26 ${ }^{\text {th }}$ March, Cornwall near Charlottetown, Canada, http://www.organicagcentre.ca/docs/carlo\%20liefert\%20organic\%20food\%20markets. pdf [Accessed October 14, 2013]

Magistris, T. and Gracia, A. (2008) "The decision to buy organic food products in Southern Italy”, British Food Journal, 110 (9): 929-947.

Magnusson, M.K., Arvola, A., Koivisto Hursti, U., Aberg, L. and Sjoden, P.O. (2001) "Attitudes towards organic foods among Swedish consumers", British Food Journal, 103 (3): 209-226.

Makatouni, A. (2002) "What motivates consumers to buy organic food in the UK?", British Food Journal, 104 (3/4/5): 354-352.

Maričić, B. (2011) Ponašanje potrošača, Beograd: Centar za izdavačku delatnost Ekonomskog fakulteta.

Marques Vieira, L., Dutra de Barcellos, M., Hoppe, A. and Bitencourt da Silva, S. (2013) "An analysis of value in an organic food supply chain", British Food Journal, 115 (10): 1454-1472.

Miller, G.T., Spoolman, S. (2008) Environment Science: Problems: Concepts and Solutions, $12^{\text {th }}$ ed., Stamford: Cengage Learning.

O'Donovan, P. and McCarty, M. (2002) "Irish consumer preference for organic meat", British Food Journal, 104 (3/4/5): 353-370.

O'Doherty Jensen, K., Denver, S. and Zanoli, R. (2011), “Actual and potential development of consumer demand on the organic food market in Europe", NJAS - Wageningen Journal Sciences, 58 (3-4): 79-84.

Ognjanov, G., Stojanović, Ž. i Filipović, J. (2010) “Kvalitativno istraživanje razloga, prepreka i stereotipa vezanih za potrošnju i potrošače voća u Srbiji”, Marketing, 41 (3): 141-150.

Padel, S. and Foster, C. (2005) "Exploring the gap between attitudes and behavior: understanding why consumers buy or do not buy organic food", British Food Journal, 107 (8): 606-625. 
Pearson, D., Henryks, J., Sultan, P. and Anisimova, T. (2013) "Organic food: Exploring purchase frequency to explain consumer behavior", Journal of Organic Systems, 8 (2): 50-63.

Renko, S. i Bošnjak, K. (2009) “Aktuelno stanje i perspektive razvoja tržišta ekološke hrane u Hrvatskoj”, Ekonomski pregled, 60 (7-8): 369-395.

Roddy, G., Cowan, C. and Hutchinson, G. (1994) "Organic food: a description of the Irish market", British Food Journal, 96 (4): 3-10.

Sangkumchaliang, P. and Huang, W.C. (2012) "Consumers' Perceptions and Attitudes of Organic Food Products in Northern Thailand", International Food and Agribusiness Management Review, 15 (1): 87-102.

Schifferstein, H. and Oude Ophuis, P. (1998) "Health-related determinants of organic food consumption in Netherlands", Food Quality and Preference, 9 (3): 119-133.

Soil Association, (2012): “Organic Market Report 2012”, Bristol (UK): Soil Association.

Soler, F. and Gil, J.M. (2002), "Consumers' acceptability of organic food in Spain: results from an experimental auction market", British Food Journal, 104 (8): 670-687.

Squires, L., Jurić, B. and Cirnwell, T. (2001) "Level of market development and intensity of organic food consumption: cross-cultural study of Danish and New Zealand consumers", Journal of Consumer Marketing, 18 (5): 392-409.

Thompson, G. and Kidwell, J. (1998), "Explaining the Choice of Organic Produce: Cosmetic Defects, Prices, and Consumer Preferences", American Journal of Agricultural Economics, 80 (2): 277-287.

Thøgersen, J. (2010) "Country Differences in Sustainable Consumption: The Case of Organic Food”, Journal of Macromarketing, 30 (2): 171-185.

Torjusen, H., Nyberg, A. and Wandel, M. (1999) "Organic food: consumers' perceptions and dietary choices, SIFO-Report, No. 5-1999,National Institute for Consumer Research, Lysaker, Norway.

Tregear, A., Dent, J.B. and McGregor, M.J. (1994) “The demand for organically grown produce", British Food Journal, 94 (4): 21-25.

Truong, T., Yap, M. and Ineson, E. (2012) 'Potential Vietnamese consumers' perceptions of organic foods", British Food Journal, 114 (4): 529-543.

Urena, F., Bernabeu, R. and Olmeda, M. (2008) "Women, men and organic food: differences in their attitudes and willingness to pay: A Spanish case study", International Study of Consumer Studies, 32(1): 18-26.

Von Alvensleben, R. (1998) "Ecological aspect of food demand: the case of organic food in Germany", AIR-CAT 4th Plenary Meeting: Health, Ecological and Safety Aspects in Food Choice, 4 (1): 68-79.

Vlahović, B., Tomić, D. i Popović, V. (2010) "Stanje i perspektive potrošnje proizvoda organske poljoprivrede", u: Forum o organskoj proizvodnji, (IV), Selenča: http://organiccentar.rs/sites/default/files/radovi sa foruma/STANJE\%20I\%20PERSPE KTIVE\%20POTRO\%C5\%A0NJE\%20PROIZVODA\%20ORGANSKE\%20POLJOPR IVREDE.pdf [Accessed September 20, 2013]

Vlahović, B., Puškarić, A. and Jeločnik, M. (2011) "Consumer attitude to Organic Food Consumption in Serbia", Petroleum Gas University of Ploiesti Bulletin, 18 (1): 45-52.

Wier, M. and Calverley, C. (2002): "Market potential for organic foods in Europe", British Food Journal, 104(1): 45-62. 
Wilkins, J.L. and Hillers, V.N. (1994) "Influences of pesticide residue and environmental concerns on organic food cooperative members and non-members in Washington state"; Journal of Nutrition Education, 26 (1): 26-33.

Willer, H., Lernoud, J. (Eds.) (2014), "The World of Organic Agriculture: Statistics and Emerging Trends 2014”, FiBL-IFOAM Report, Research Institute of Organic Agriculture (FiBL), Frick, and International Federation of Organic Agriculture Movements (IFOAM), Bonn, February.

Wang, Q., Halbrendt, C. and Webb, S. (1997) "Consumer demand for organic food in China: Evidence from survey data“, In: Lockertz (ed.), Agricultural production and Nutrition, Boston (Massachusetts): Tufts University, pp. 187-194.

Wolf, M.M. (2002) "An analysis of the impact of price on consumer interest in organic grapes and a profile of organic purchasers", American Agricultural Economics Association Annual Meeting, Long Beach, 28-31 July, California,http://ageconsearch.umn.edu/bitstream/19663/1/sp02wo02.pdf [Accessed October 18, 2014].

Zakowska-Biemans, S. (2007) "Consumers and consumption of organic food in Central and Eastern European new member states of the European Union", 3th QLIF Congress: Improving Sustainability in Organic and Low Input Food Production Systems, 20-23 March, University of Hohenheim, Germany, http://orgprints.org/9806/1/zakowska2007-ConsumerEasternEurope.pdf [Accessed October 23, 2014]

Zakowska-Biemans, S. (2009) "Factors underlying consumption of organic food in the opinion of Polish consumers", Agonomy Research, 7 (2 special issue): 768-774.

Zakowska-Biemans, (2011), "Polish consumer food choices and beliefs about organic food", British Food Journal, 113(1): 122-137.

Zanoli, R. and Naspeti, S. (2002) "Consumer Motivations in the Purchase of Organic Food", British Food Journal, 104 (8): 643-653.

Zanoli, R. and Jukic, N. (2005) "Marketing study on organic and other selected special quality products from Croatia", Final Publishable Report,http://www.fao.org/docs/eims/upload/ 229929/2005_12_doc01.pdf [Accessed February 20, 2014]

Znaor, D. (1996) Ekološka poljoprivreda, Zagreb: Nakladni zavod.

\section{ISTRAŽIVANJE MOTIVA POTROŠAČA KOJI UTIČU NA KUPOVINU ORGANSKE HRANE U SRBIJI}

Apstrakt: Tržište organske hrane u Srbiji je u početnoj fazi razvoja i može se smatrati tržištem u nastajanju. Dubljim razumevanjem motivacije potrošača moguće je kroz adekvatan marketing pristup obezbediti veću potrošnju organske hrane po glavi stanovnika i brži razvoj nacionalnog tržišta. U ovom radu predstavljen je deo najvažnijih nalaza do kojih je autor došao na osnovu sprovedenog kvantitativnog istraživanja potrošača u Srbiji. Istraženi su i analizirani glavni razlozi i prepreke za kupovinu organske hrane, kao i spremnost kupaca da plate višu cenu za organske prehrambene proizvode u odnosu na alternativne proizvode iz konvencionalne proizvodnje. Predstavljeni rezultati podržavaju teorijsko znanje stečeno iz brojnih istraživanja prethodno sprovedenih u različitim zemljama. Polazeći od dobijenih rezultata istraživanja, u zaključku su date preporuke za implementaciju uspešnih strategija instrumenata marketing miksa.

Ključne reči: organska hrana, motivacija, potrošači, tržište, Srbija 